\title{
ÍNDICE DE ASSUNTOS
}

$\begin{array}{ll}\text { Abordagem estrutural } & 68\end{array}$

$\begin{array}{ll}\text { Aspecto verbal } & 204\end{array}$

$\begin{array}{ll}\text { Círculo de Bakhtin } & 169\end{array}$

$\begin{array}{lr}\text { Construções com verbo-suporte } & 204\end{array}$

$\begin{array}{lr}\text { Diálogo } & 101,169\end{array}$

$\begin{array}{ll}\text { Diários reflexivos } & 230\end{array}$

$\begin{array}{ll}\text { Editorial } & 101\end{array}$

$\begin{array}{ll}\text { Ensino a distância EAD } & 230\end{array}$

$\begin{array}{ll}\text { Ensino de línguas para crianças } & 230\end{array}$

$\begin{array}{ll}\text { Enunciação } & 56\end{array}$

$\begin{array}{lr}\text { Enunciado } & 169\end{array}$

$\begin{array}{ll}\text { Escravidão } & 35\end{array}$

$\begin{array}{ll}\text { Etiqueta } & 145\end{array}$

Família

$\begin{array}{lr}\text { Folha de S.Paulo } & 101\end{array}$

$\begin{array}{ll}\text { Formas de tratamento } & 145\end{array}$

$\begin{array}{lr}\text { Harry Potter } & 169\end{array}$

$\begin{array}{lr}\text { Ideologia } & 169\end{array}$

$\begin{array}{ll}\text { Influências históricas } & 68\end{array}$

$\begin{array}{ll}\text { Interação } & 10\end{array}$

$\begin{array}{ll}\text { Jornalismo digital } & 101\end{array}$

$\begin{array}{ll}\text { Letramento em avaliação de línguas } & 230\end{array}$ 
Léxico-gramática

Marcadores discursivos 10

$\begin{array}{ll}\text { Modalidades epistêmicas } & 129\end{array}$

$\begin{array}{ll}\text { Percursos figurativos e temáticos } & 129\end{array}$

$\begin{array}{ll}\text { Relações de discurso } & 10\end{array}$

Semântica do Acontecimento $\quad 35,56$

$\begin{array}{ll}\text { Senhor } & 35\end{array}$

$\begin{array}{ll}\text { Sociolinguística Variacionista } & 68\end{array}$

$\begin{array}{ll}\text { Sujeito } & 56\end{array}$

$\begin{array}{ll}\text { Triagem e Mistura } & 129\end{array}$

$\begin{array}{ll}\text { Uso estilístico } & 145\end{array}$

$\begin{array}{ll}\text { Variação linguística } & 145\end{array}$ 